\title{
Challenging Dehumanization in U.S. Sex Offender Policy by Listening to Silenced Voices
}

\author{
D J Williams, $\mathrm{PhD}$ \\ Idaho State University \\ Center for Positive Sexuality (Los Angeles)
}

\section{Introduction: Sex-Negativity and Ineffective Policy}

Growing research in the area of sexual offending shows that current policy in America is very costly, yet ineffective. In a landmark review, Quinn, Forsythe, and Mullen-Quinn (2004) identified and traced the origins of common myths concerning sexual offending, which are widely believed among both lay people and professionals. These myths include: (a) that sexual offenders and their motivations are all the same; (b) that sexual offenders are "predators" and will nearly always re-offend; and (c) that sexual offender treatment is ineffective. A recent literature review by scholars from the Center for Positive Sexuality found that current policy is based largely on these myths and that these myths are rooted in widespread cultural sexnegativity and fear, which then contribute to the stigmatization and dehumanization of sexual offenders and their families (Williams et al., 2015). Unfortunately, we should reasonably expect that policy rooted in sex-negativity and myths, rather than scholarship, will be ineffective and perhaps increase offenders' risk for re-offense, rather than decreasing it.

In this paper, I will begin by summarizing research on sexual offending issues and the trend to create harsher laws and policies, which then often contributes to dehumanization. Besides ethical implications around dehumanization, the process of dehumanization amplifies risk for future violence. Sexual offending is, obviously, a serious issue, and offenders must be accountable for their crimes and learn to manage specific risks for re-offense. However, the best way to effectively address sexual offending issues and reduce sexual violence is to draw heavily from scholarly research, theory, and principles of ethical practice in developing policy. In the U.S., we have yet to do this. After briefly summarizing the literature, I will address dehumanization directly by empowering the voices of treated sexual offenders and, in some cases, family members. The prioritization herein of voices that are frequently silenced is a significant contribution to the academic and professional literature.

\section{Recidivism Rates and Treatment Effectiveness}

Contrary to popular belief, a large and growing body of research suggests that sexual offenders generally reoffend at lower rates than other classifications of offenders and that well-designed treatment programs have a statistically and clinically significant effect on reducing recidivism. For example, a recent meta-analysis by Walton and Chou (2015) found an overall recidivism rate of $18.6 \%$ for untreated sexual offenders compared to $13.9 \%$ for those who received treatment. Other large reviews consistently have reported low recidivism rates for sexual offenders (i.e., Center for Sex Offender Management, 2001; Hanson \& Bussiere, 1998; Soothill, 2010). 
Thorough research reviews have also found evidence for sexual offender treatment effectiveness (Hanson et al., 2009; Losel \& Schmucker, 2005; Marshall et al., 2007). Despite some methodological issues in evaluating treatment scientifically over long periods of time (Hanson, 2014), the large body of available research runs contrary to pervasive myths about sexual offending recidivism rates and treatment effectiveness.

\section{Recent Policy Based on Rare, Horrific Cases}

In the past two decades, sexual offender policy has become more expansive, punitive, and dehumanizing. Such harsh policy applied to sexual offenders broadly is driven by public anger following a very small number of the most tragic cases where children have been assaulted and murdered (Griffin \& Stitt, 2010). Policy now has expanded to the point that some "sexual offenses" arguably are not sexual, such as urinating in public, and others are not conspicuously criminal, such as sexting, yet those convicted of such transgressions are subject to the same longterm legal ramifications as other sexual offenders (Williams et al., 2015). At the same time, there are large numbers of "offenders" who are 18 years of age or slightly older, but who had consensual sexual interactions with partners who were slightly under age 18. Such cases would not be crimes in many nations.

Sexual offenses of all varieties carry long prison sentences. For example, in Utah it was recently reported that sexual offenders now take up $42 \%$ more prison beds than a decade ago, which at this rate means that soon the Utah State Prison will only have room for those convicted of sexual offenses and murder (Lang, 2014). Furthermore, sexual offender policy has become so punitive that some states sought capital punishment for sexual (but non-homicidal) offenses (Gibeaut, 2007), though such legislation has been deemed unconstitutional by the United States Supreme Court (Kennedy v. Louisiana).

\section{Increased Risk and Collateral Damage}

Studies show that sexual offenders often face severe stigmatization, which leads to resentment, fear, and hopelessness (Jahnky et al., 2014; Tewksbury, 2012). Notification laws have also resulted to high percentages of sexual offenders experiencing property damage, threats, or assault (Brannon et al., 2007; Robbers, 2009). Sex offenders who experience isolation from their communities and violence are at higher risk for re-offense. Levenson and Tewksbury (2009) found that family members of sexual offenders are negatively impacted by sexual offender notification laws. Levenson and Tewksbury reported that family members are more likely to experience threats and harassment from neighbors, and that children of sexual offenders are very likely to experience negative effects in their relationships with other children and also adults. These researchers further reported that very high percentages of sexual offenders' children exhibit anger, depression, anxiety, feeling left out by peers, and fear, while $13 \%$ of children in the study were reported to show suicidal tendencies. Despite these substantial problems, researchers have found that many policymakers and practitioners believe that current policy is effective in addressing sexual violence (Meloy et al., 2013). 
Research strongly suggests that there is a critical need for sexual offending policy to become more inclusive and humanizing toward offenders, emphasize ethics and healing for all involved, and move away from legislation driven by fear (Williams et al., 2015). A more humanizing, inclusive stance rooted in restorative justice, rather than harsh retribution, lowers offenders' risk for recidivism; promotes healing for victims, offenders, and loved ones of those involved; while also reducing additional harm and injustice that many offenders and their families experience. Offenders certainly should be held accountable for their crimes, yet they should also be supported in their positive efforts to change with the goal to live crime free within their communities.

\section{Human Identities and Simple Words from Silenced Voices}

In the remainder of this paper, I will highlight the voices of successfully treated sexual offenders with whom I worked in clinical practice (aftercare program) and, in a few instances, their family members and colleagues. Permission was granted by these former clients to share excerpts from selected materials. Arditti (2002; Arditti et al., 2010) reported that it is important for academics and professionals to become more sensitive to the experiences and traumas of both offenders and their families, yet to date, these voices largely have been devalued and dismissed. This recommendation is consistent with the recent critical approach, convict criminology, in academia, which focuses on the needs and experiences of prisoners in order to improve correctional policy and reduce recidivism (for a review, see Richards, 2013). Judith Brink, who worked as a chaplain in prison, wrote, "Mothers, fathers, wives, husbands, sisters, brothers, and children of prisoners suffer the same isolation, discrimination, and financial and emotional burdens that prisoners do" (2003, p. 393). We should remember that sexual offenders have important human qualities and common identities, such as partners, fathers, sons, brothers, students, or employees (1).

\section{"I’ve Missed Talking to You"}

Many sexual offenders are fathers who love and miss their children, and their children love and miss them. The following words were written in a card sent by the adult, married daughter to her father, an older man who was convicted of a sexual offense 11 years earlier. Printed on the card are the words: Been thinking about you, but that's nothing new...Anytime's perfect for thinking of you! This thoughtful daughter clearly missed her father and wrote a long heartfelt note, including the words, "Dad, I know you called on my birthday, but we weren't home. I've missed talking to you, and hope to talk to you soon. I miss and love you lots! Hope you enjoy this card” (smile drawn in addition to her signature).

Many sexual offenders are also the parents of younger children. One of my former clients kept a picture of his three-year old daughter in his wallet. In a note, he wrote:

I last saw my little girl in 1991, when her mom brought her to visit me in prison. I miss my daughter very much! To cope, I've tried to convince myself that she has been better off with the family that has taken care of her since her mom left. I cry sometimes when I watch TV and see parents who have lost their children. The biggest reminder of the 
consequences of my actions is to look at her picture and wonder what happened to my baby girl.

Another middle-aged man with no prior felony convictions became very angry after his two-year old daughter was accidentally run-over by a car and killed in a tragic accident. Following this horrific accident, he impulsively committed several crimes, including an unplanned, opportunistic rape. He was given a very long prison sentence, and I worked with him for several months when he finally was paroled. He, too, kept a picture of the happy-go-lucky two-year old daughter that he tragically lost in his wallet. He explained:

I keep dreaming of her playing in the sand out in back of the house. In my dream she's happy. She looks peaceful, just playing in the sand with her little toy bucket. Scooping up sand. Dumping it in the bucket. She'd come in the house with sand all over her clothes. Sand in her hair. Sand everywhere! In the dream she plays in the sand for hours. She plays forever. She doesn't get hurt. She's always alive. She looks at me and says, "I love you daddy." She's probably still playing in the sand somewhere. But, I'll never get it out of my head how when I came back home that day she was laying in the sand with her tiny hand clutching the toy shovel and seeing blood dripping from her lips.

\section{“I'm Surviving, but I'm not Really Living"}

A former client contacted me while I was working on my doctoral studies to inform me that his mother, with whom he was very close, had died. He mentioned that he was processing this loss in his aftercare group and with his therapist and parole officer. He wrote:

By all appearances I'm handling it pretty well, I guess. I've shared with my sister, my brother, my ex-wife, and other family members. I'm still out (of prison). Staying out of trouble. Finishing therapy next week. But I hurt every day. I'm still working - the same job even. I'm using all the (therapeutic) tools I know, and I'm surviving, but I'm not really living. So I guess in a nutshell, I'm struggling but not falling.

Another former client wrote a letter during that same time period telling me of his many unsuccessful struggles in trying to find employment, and also to inform me that his older brother, who many years earlier had reported him to the authorities for committing sexual abuse, had died of cancer. In his letter, my former client stated:

He was the one that I threatened to kill when he turned me in for abuse. There was a protective order in place and I could not talk to him. I feel so terrible and I can never take my words back. He didn't want to go through chemo again. And now he's dead and I still cry. I really did love him. He only wanted to love and protect me all of my life. He was always a person that everyone loved.

"He will go out of His Way to Help Others" 
Another former client had completed treatment, finally landed a job, and was experiencing success at his employment. Finding employment is one of the most difficult aspects of trying to transition back into the community for sexual offenders. He proudly gave me a copy of a letter that his boss had written, which included the following:

$\mathrm{N} L$ has been in my employment for almost a year now. He is very dependable, and he will go out of his way to help others. I have seen development in his social skills. N L is very friendly with our customers and enjoys good conversation of the events of the day. He enjoys a good joke; we try to keep a happy, friendly atmosphere here. N L has fit in perfectly. There is a great deal of trust given to N L not only by myself, but from everyone that he works with.

Another former client had a long and very successful career making and repairing violins. He sent me an old catalog that mentioned his name as one of technicians who helped produce the instruments of some of the world's greatest violinists. Because of his specialized occupation and career success prior to his offense, this man was one of very few who had difficulty finding and maintaining employment following conviction.

\section{"You will be Greatly Missed"}

One former client, like virtually all of his peers, found it extremely difficult to transition from prison back into the community. He struggled to try to find employment, which was a condition of his parole, and he and his family seemed to face severe stigmatization in the community. This young man ended up re-incarcerated due to a parole violation, and I later learned that he had ended his life. When I learned of his death, I located a copy of his obituary, which I continue to keep along with the other items from former clients. The obituary is brief and includes only a few simple words. After mentioning his name, place of birth and the dates of his birth and death, it reads, "(He) is survived by his mother, a brother, his young son, grandmother, several aunts, uncles, cousins, and friends. Our beloved Son, Brother, Daddy, and Friend-You will be greatly missed."

\section{Conclusion}

Despite the personal harms that many sexual offenders have caused, the rampant stigmatization, dehumanization, and exclusion of sexual offenders is unethical and likely amplifies risk for reoffense rather than decreases it. Dehumanization runs counter to research on effective offender rehabilitation, which emphasizes accountability, support in offenders' efforts to change, and community reintegration. Although many sexual offenders have committed serious crimes, they are not monsters - they are often members of our neighborhoods, our communities, and our families. Inclusion and humanization are important aspects of positive sexuality, and applying a positive sexuality framework to sexual offending policy is capable of promoting offender accountability, supporting risk-reduction, and reducing dehumanization, thus correcting major deficits of current policy (Williams, et al. 2015). 
In understanding and responding to crime, it is important to acknowledge and address the difficult experiences and emotions of all people involved. Scholars have highlighted the need to bring a "qualitative consciousness" to the study of marginalized populations, which empowers the voices and perspectives of those being studied (Arditti, et al., 2010; Byrne, 2005). This is yet to happen with respect to sexual offenders and their loved ones, yet by doing so we may gain valuable insights into how to more effectively promote healing and reduce future victimization. Perhaps through a willingness to engage and listen to silenced voices, along with academic and professional voices, we may make greater strides in reducing and preventing violence, dehumanization, and injustices of multiple varieties.

\section{Note}

1. I use male nouns herein given that the vast majority of sexual offenders are males.

\section{Acknowledgment}

The author extends gratitude to former clients who shared letters and personal items that were presented in this article. The author wishes these men continued success in their efforts to live crime-free

\section{References}

Arditti, J. A. (2002). Doing family research at the jail: Reflections of a prison widow. Qualitative Report, 7(4).

Arditti, J. A., Joest, K. S., Lambert-Shute, J., \& Walker, L. (2010). The role of emotions in fieldwork: A self-study of family research in a corrections setting. Qualitative Report, 15, 1387-1414.

Brannon, Y. N., Levenson, J. S., Fortney, T., \& Baker, J. N. (2007). Attitudes about community notification: A comparison of sexual offenders and the non-offending public. Sexual Abuse: A Journal of Research and Treatment, 19, 369-379.

Brink, J. (2003). You don't see us doin' time. Contemporary Justice Review, 6, 393-396.

Byrne, M. (2005). Conducting research as a visiting scientist in a women's prison. Journal of Professional Nursing, 21, 223-230.

Center for Sex Offender Management. (2001). Recidivism of sex offenders. Silver Spring, MD.

Gibeaut, J. (2007). A deal with death. American Bar Association Journal (January Issue): 12-13.

Griffin, T., \& Stitt, R. G. (2010). Random activities theory: The case for a "black swan" criminology. Critical Criminology, 18, 5772.
Hanson, R. K. (2014). Treating sexual offenders: How did we get here and where are we headed? Journal of Sexual Aggression, 20, 3-8.

Hanson, R. K., Bourgon, G., Helmus, L., \& Hodgson, S. (2009). The principles of effective correctional treatment also apply to sexual offenders: A meta-analysis. Criminal Justice and Behavior, 36, 865-891.

Hanson, R. K., \& Bussiere, M. T. (1998). Predicting relapse: A meta-analysis of sexual offender recidivism studies. Journal of Consulting and Clinical Psychology, 66, 348-362.

Jahnke, S., Imhoff, R, \& Hoyer, J. (2014). Stigmatization of people with pedophilia: Two comparative surveys. Archives of Sexual Behavior, 44, 21-34.

Lang, M. (September 14, 2014). Sex offenders driving up Utah prison population. Salt Lake Tribune.

Levenson, J., \& Tewksbury, R. (2009). Collateral damage: Family members of registered sex offenders. American Journal of Criminal Justice, 34, 54-68.

Losel, F., \& Schmucker, M. (2005). The effectiveness of treatment for sexual offenders: A comprehensive meta-analysis. 
Journal of Experimental Criminology, 1, 117-146.

Marshall, W. L., Marshall L. E., \& Serran, G. A. (2007). Strategies in the treatment of paraphilias: A critical review. Annual Review of Sex Research, XVII, 162-182.

Meloy, M. L., Boatwright, J., \& Curtis, K. (2013). Views from the top and bottom: Lawmakers and practitioners discuss sex offender laws. American Journal of Criminal Justice, 38, 616-638.

Quinn, J. F., Forsythe, C. J., \& Mullen-Quinn, C. (2004) Societal reaction to sex offenders: A review of the origins and results of the myths surrounding their crimes and treatment amenability. Deviant Behavior, $25,215-232$.

Richards, S. C. (2013). The new school of convict criminology thrives and matures. Critical Criminology, 21, 375-387.

Robbers, M. L. P. (2009). Lifers on the outside: Sex offenders and disintegrative shaming. International Journal of Offender Therapy and Comparative Criminology, 53, 5-28.

Soothill, K. (2010). Sex offender recidivism. Crime and Justice, 39, 145-211.

Tewksbury, R. (2012). Stigmatization of sex offenders. Deviant Behavior, 33, 606-623.

Walton, J. S., \& Chou, S. (2015). The effectiveness of psychological treatment for reducing recidivism in child molesters: A systematic review of randomized and nonrandomized studies. Trauma, Violence, and Abuse, 16, 401-417.

Williams, D J, Thomas, J. N., \& Prior, E. E. (2015). Moving full-speed ahead in the wrong direction? A critical examination of U.S. sex offender policy from a positive sexuality model. Critical Criminology, 23, 277-294. 